\title{
Forage seed production and trade as a pathway out of poverty in the smallholder sector: lessons from the Zimbabwe Crop Livestock Integration for Food Security (ZimCLIFS) project
}

Irenie Chakoma, Lovemore C Gwiriri, Godfrey Manyawu, Sikhalazo Dube, Mercy Shumba \& Aleck Gora

To cite this article: Irenie Chakoma, Lovemore C Gwiriri, Godfrey Manyawu, Sikhalazo Dube, Mercy Shumba \& Aleck Gora (2016) Forage seed production and trade as a pathway out of poverty in the smallholder sector: lessons from the Zimbabwe Crop Livestock Integration for Food Security (ZimCLIFS) project, African Journal of Range \& Forage Science, 33:3, 181-184, DOI: 10.2989/10220119.2016.1173097

To link to this article: http://dx.doi.org/10.2989/10220119.2016.1173097

\section{Published online: 26 Aug 2016.}

6 Submit your article to this journal $\square$

山 Article views: 23

View related articles

View Crossmark data $₫$ 


\title{
Forage seed production and trade as a pathway out of poverty in the smallholder sector: lessons from the Zimbabwe Crop Livestock Integration for Food Security (ZimCLIFS) project
}

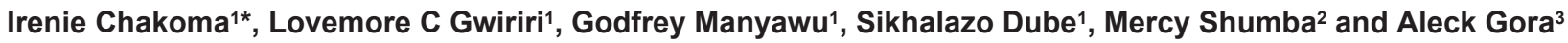 \\ 1 International Livestock Research Institute, c/o CIMMYT Southern Africa Regional Office, Harare, Zimbabwe \\ 2 Community Technology Development Organisation, Harare, Zimbabwe \\ ${ }^{3}$ Cluster Agricultural Development Services, Harare, Zimbabwe \\ * Corresponding author, email: i.chakoma@cgiar.org
}

\begin{abstract}
The major challenge to adoption of improved forage technologies in the smallholder farming sector is poor accessibility to seed of improved cultivars. Since 2012, the Zimbabwe Crop Livestock Integration for Improved Food Security (ZimCLIFS) project set out to address such challenges through research-for-development initiatives. The main objective was to demonstrate the potential viability of a pasture seed business using a lead farmer approach, farmer-to-farmer technology dissemination, innovation platforms and field demonstrations. Snapshot surveys were used to map forage seed distribution pathways within and outside project areas. Total land area planted to forages from the $2012 / 13$ to $2014 / 15$ seasons increased by $147 \%$ from 14.6 ha. In 2013 , Mucuna pruriens (mucuna), Lablab purpureus (lablab) and Vigna unguiculata (cowpea) seed produced was $2250 \mathrm{~kg}, 120 \mathrm{~kg}$ and $4450 \mathrm{~kg}$, respectively, and by the third season, total yield increased by $163 \%$. Seed diffusion was within and beyond project boundaries, with mucuna $(67 \%)$ and lablab $(43 \%)$ seed produced in the $2013 / 14$ season being distributed outside the project area. Highest amounts received by some farmers were US $\$ 800$ and US $\$ 750$ for lablab and mucuna, respectively. It was concluded that there is scope to develop formal pasture seed businesses to increase rural industrialisation and provide a pathway out of poverty in the smallholder sector.
\end{abstract}

Keywords: forage legumes, income, seed marketing, Zimbabwe

Seed is a very important input in agriculture and sustainability is not guaranteed if access to improved cultivars is hampered (Welu 2015). With the projected increase in demand for livestock and livestock products, more feed will be required for livestock (Thornton 2010) and rangelands alone will not sustain livestock (FAO 2011). Therefore, seed for livestock fodder and pasture is critical for livestock production.

Previous authors have concluded that limited forage seed supply remains one of the major challenges affecting adoption of improved forage cultivars in livestock systems in most parts of Africa and Asia (Phaikaew et al. 1997; Shelton et al. 2005; Mapiye et al. 2006). Forage seed production and marketing is often hampered by the perceived risk (seed quality, costs of inputs and markets, among others) of forage seed production, the long period between investment and realisation of income, i.e. from planting of the forages to livestock sales, and lack of information on forage production and its associated value. In Zimbabwe, forage seed is scarce and, if available, is expensive (Mapiye et al. 2006). To that end, access to forage seed by smallholder farmers continues to impact negatively on adoption of technologies that are forage based. The main objective was to demonstrate potential viability of a pasture seed production business in smallholder systems.

The study was carried out in the Goromonzi and Murehwa districts, which are located in Mashonaland East province in agro-ecological region II in Zimbabwe. Agro-ecological region II receives annual rainfall that ranges between 700 and $1000 \mathrm{~mm}$. Rainfall is received between November and April, and the annual average maximum and minimum temperatures are $25^{\circ} \mathrm{C}$ and $10^{\circ} \mathrm{C}$, respectively.

Data were collected on the background of the Zimbabwe Crop Livestock Integration for Food Security (ZimCLIFS) project, which commenced in 2012. The project was implemented by ILRI in collaboration with other CGIAR centres (CIMMYT and ICRISAT), non-governmental organisations (Community Technology Development Organisation and Cluster Agricultural Development Services) and government departments (Livestock Production and Development [LPD] and Agricultural Technical and Extension Services [AGRITEX]). The project's overall goal was to identify, test and prove ways to increase agricultural production, improve household food security, alleviate poverty and thereby reduce food-aid dependency in rural communities through better integrated crop and livestock production and market participation. In a bid to achieve this, the project conducted 
research-for-development activities on fodder production, conservation and marketing, including seed production and marketing, livestock feeding and enhancement of value chains.

Approaches used for engagement were a lead farmer approach, farmer-to-farmer technology dissemination, innovation platforms, field demonstrations and multistakeholder roundtables. Volunteer farmers received seed at rates of $25 \mathrm{~kg} \mathrm{ha}^{-1}$ each of Lablab purpureus 'Highworth' and 'Rongai' (lablab), and Vigna unguiculata 'CBC3' (cowpea), and $40 \mathrm{~kg} \mathrm{ha-1}$ of Mucuna pruriens var. utilis (mucuna), depending on land area to be planted that season. Training sessions were conducted for farmers and extension staff on forage production and conservation, and seed production.

Researchers, extension staff and non-governmental organisation partners held meetings with farmers to discuss forage production costs incurred during the past season using an iterative process. Having established a production cost and tentative selling price for each forage crop, an innovation platform roundtable was organised with stakeholders in the seed industry, research sector, university representatives and input suppliers to discuss and negotiate on the price. Following a Continuous Improvement and Innovation model (Clark and Timms 1999), three roundtable negotiations were held to negotiate the price.

Forage seed cost of production was calculated taking into account inputs (seed, fertilisers and chemicals), land preparation and labour (planting, weeding, spraying and harvesting). Costs of production were derived using data collected from farmers producing forage seed over the three seasons (2012/13 to 2014/15).

From the seed distributed to farmers, a total of 105 farmers planted forages in the $2012 / 13$ season, with an increase of more than $133 \%$ by the $2014 / 15$ season. The area under forage production also increased by $147 \%$ from 14.6 to 36.2 ha in the $2014 / 15$ season. The greatest increase in area was for mucuna, followed by lablab and cowpea.

There was a total increase of $163 \%$ in seed production from the $2012 / 13$ to $2014 / 15$ seasons. Seed production for mucuna alone increased by more than $244 \%$ (4 $500 \mathrm{~kg}$ in $2013 / 14$ to $15500 \mathrm{~kg}$ in the 2014/15 season) in the third season as seed was shared and more farmers planted the forages within the communities. During the same period, there was a decrease of $58 \%$ in area planted to lablab in the $2014 / 15$ season. In addition, cowpea seed produced in the 2013/14 season decreased from that of the previous season.

Through innovation platforms, valuable information and knowledge was shared on farmer seed production processes, farmer groups, seed demand, market linkages and farmer-stakeholder-buyer perceptions. This involved a forum where farmers discussed local specific production and marketing systems with stakeholders through an iterative process.

Indications from the three seasons of production were that cowpea production cost per kilogram was greater than that of lablab and mucuna. Mucuna showed the greatest seed yield, whilst lablab seed fetched the best price compared with the other two forages.
A snapshot survey involving 77 farmers from the Goromonzi and Murehwa districts was conducted in 2014 to determine how forage seed produced was utilised and disseminated (Table 1). The distribution pathways used by the farmers were seed exchanges, gifts, sales and payment for labour, whilst some of the seed was retained and some fed to livestock. Responses were received from 47, 9 and 21 farmers that grew mucuna, lablab and cowpea, respectively, of which 25 farmers grew a combination of the legumes.

All interviewed farmers indicated some level of cowpea consumption within the household and amounts ranged between 50 and $75 \mathrm{~kg}$ household ${ }^{-1}$. No consumption was recorded for mucuna and lablab. Most farmers retained some seed irrespective of type. Farmers who sold seed constituted $72 \%, 33 \%$ and $28 \%$ of those with mucuna, lablab and cowpea, respectively. Seed sales were mainly to dairy centres and individual buyers outside ward boundaries. Two farmers among those who sold large quantities each realised US $\$ 800$ and US $\$ 750$ from the sale of $200 \mathrm{~kg}$ lablab and $250 \mathrm{~kg}$ mucuna, respectively. Generally, mucuna was popular with farmers on all distribution pathways used. All farmers who had grown the forage crop managed to harvest some seed, unlike lablab which was retained and then distributed. Seed production of mucuna proved easier compared to that of lablab. Gifts to friends, relatives and neighbours were greatest for mucuna followed by cowpea, with quantities ranging between 1 and $25 \mathrm{~kg}$.

A few farmers used mucuna and lablab seed to pay for hired labour. Seed quantities given were equated to US\$5.00 per labour day. Mucuna, lablab and cowpea were valued at US\$3.00 kg-1, US\$4.00 kg-1 and US\$1.00 kg-1, respectively. Farmers (38\% of respondents) used mucuna and cowpea in livestock feed rations. This was mixed with other ingredients such as crushed maize, forage hay and maize stover to constitute the diets.

The programme expanded into the Manicaland, Mashonaland Central and Matabeleland North provinces where more than 200 farmers bought over $3000 \mathrm{~kg}$ of mucuna and lablab seed, which was planted to around 50 ha. Additional seed of mucuna was exported to Swaziland for demonstrations on seed production and beef cattle fattening.

Adoption of forage technologies by farmers depends on availability of seed, knowledge, access to finance and market access, among other factors (Mapiye et al. 2006; Beshir 2014). The initial seed distribution conducted on the ZimCLIFS project enabled farmers to access forage

Table 1: Utilisation and dissemination pathways used by farmers in Goromonzi and Murehwa districts, Zimbabwe. A greater number of ticks indicates increased farmer involvement in the distribution pathway

\begin{tabular}{lccc}
\hline $\begin{array}{l}\text { Utilisation and } \\
\text { distribution pathway }\end{array}$ & $\begin{array}{c}\text { Farmers with } \\
\text { mucuna }\end{array}$ & $\begin{array}{c}\text { Farmers with } \\
\text { lablab }\end{array}$ & $\begin{array}{c}\text { Farmers with } \\
\text { cowpea }\end{array}$ \\
\hline Consumed & Nil & Nil & $\checkmark \checkmark \checkmark$ \\
Exchanged & $\checkmark$ & $\checkmark$ & $\checkmark$ \\
Gifts & $\checkmark \checkmark$ & $\checkmark$ & $\checkmark \checkmark$ \\
Retained & $\checkmark \checkmark \checkmark$ & $\checkmark$ & $\checkmark \checkmark$ \\
Paid hired labour & $\checkmark$ & $\checkmark$ & Nil \\
Livestock feed & $\checkmark \checkmark$ & $\checkmark$ & $\checkmark \checkmark$ \\
Sales & $\checkmark \checkmark \checkmark$ & $\checkmark$ & $\checkmark$ \\
\hline
\end{tabular}


seed of mucuna, lablab and cowpea and there was also sharing of information during seed exchanges. Although in smallholder systems farmers often access seed through informal channels, a more formal channel is required to ensure availability of quality seed (Guei et al. 2011; Hare 2014; Welu 2015). Cowpea has been produced in the area for food, and other cowpea cultivars are suitable for forage production (Ayan et al. 2012) and produce hay that has a balanced nutrition for livestock (Singh et al. 2003). From the present study there are indications that farmers now have more options for the use of the crop. Mucuna was also adopted by farmers as it was perceived as a crop with low management requirements and profuse seed production.

Mucuna produced abundant quantities of seed in each season, indicating its adaptability to the environment and profuse seeding ability. The lablab cultivar 'Rongai', on the other hand, did not produce seed, suggesting that the season was too short for the crop. Seed production is affected when the growing season ends before maturity is attained and in areas where frost is prevalent (Murphy and Colucci 1999). Mucuna seed production increased among farmers because of ease of production, the crop is less prone to diseases and pests, and has fewer limitations to its seed-setting capacity. Farmers conserved a total of 4750 $\mathrm{kg}$ hay from cowpea, unlike in the first season where $90 \%$ of the farmers who planted cowpea preferred to harvest seed rather than conserve forage as hay. Conserved forage of mucuna, lablab and cowpea increased over the seasons as farmers also collected the residue to feed to their livestock after harvesting seed.

Innovation platforms played a pivotal role in the districts as discussion fora for farmers and stakeholders on the development and strengthening of forage seed markets and the industry as a whole. Clark and Timms (1999) stressed the importance of continuously engaging the farmers to achieve set objectives. This concurs with the suggestion by Njingulula et al. (2014) that participation of stakeholders, including the public sector, in innovation platforms creates opportunities for farmers to find lucrative markets for seed. The private sector has the capacity to develop the forage seed business and enhance its viability (Roothaert et al. 2006; Njingulula et al. 2014). In addition, according to Martey et al. (2014), farmers are willing to participate in innovation platforms if it is convenient and beneficial for them.

There is a need for back-up support to extension staff who give advice to farmers in the form of Training of Trainers, farmer trainings, exchange visits and demonstrations. As suggested by Uzonna and Qijie (2013) and Tsado et al. (2014), farmer training is of utmost importance to enhance uptake of technologies. This will create direct and indirect benefits to farmers, and improve resilience to negative effects of droughts in Zimbabwe.

Farmers were able to realise income from the sale of forage seed, which boosted their income sources and diversity of farm activities (Table 2). This could be associated with the market prices for the forages existing at that time, namely US\$1.00 kg-1 for cowpea, US\$3.00 kg-1 for mucuna and US\$4.00 kg-1 for lablab. When seed prices are favourable, farmers will readily engage in forage seed production and will fully participate in the value chain. Forages have been found to have high gross margins because of lower production costs compared with other field crops (Hare 2014). Indications from the ZimCLIFS project are that production costs for mucuna (US $\$ 0.40 \mathrm{~kg}^{-1}$ ) are lower than those of lablab (US\$0.49 $\mathrm{kg}^{-1}$ ) and cowpea (US\$0.53 $\mathrm{kg}^{-1}$ ). According to Vissoh et al. (1998), adoption of mucuna seed production can be enhanced with development of new and viable markets.

Other benefits derived from forage seed production and marketing were knowledge on how seed markets function and the interaction with seed market players.

Distribution pathways used by farmers indicate that there is scope to increase access to seed by farmers within communities (Hare et al. 2013; Alemu 2015). Seed exchanges and gifts also offer a platform for good relations among communities and easy seed supply, and this enhances resilience among farmers. These features, within the informal system, deal with small seed quantities required by farmers at the local level (Alemu 2015). This informal system has been viewed as sustainable as farmers gain access to seed, although it is considered uneconomic to the producers because it is governed by social relations that exist (Beyene 2010). The system has been viewed as not guaranteeing farmers high-quality seed (Alemu 2015) and there is a need to combine it with the formal system for maximum benefits (Etwire et al. 2013).

Forage seed access among farmers is important as forage legume crops, including mucuna, have high nitrogenfixing ability, contribute significant quantities of nitrogen to the soil through green manuring, especially mucuna (Ambrosano et al. 2013; Mhlanga et al. 2015), and thus improve soil fertility and structure. Forages (mucuna, lablab and cowpea) have also been used successfully in livestock feed rations (Belewu and Olajide 2010; Buwu 2014), despite containing anti-nutritional factors (D'Mello and Devendra 1995).

It can be concluded that forage seed income contributes significantly to household income sources and livelihoods. Therefore, marketing channels that can enhance forage seed supply, production and sale become important for the smallholder sector. Opportunities exist for smallholder farmers to make a business from forage seed production and trade with support from the private and public sector, non-governmental organisations and extension services.

Table 2: Production costs incurred and income realised from forage seed in the Goromonzi and Murehwa districts, Zimbabwe. Values are the average of three seasons

\begin{tabular}{|c|c|c|c|}
\hline Revenue & Lablab & Mucuna & Cowpea \\
\hline Seed yield $\left(\mathrm{kg} \mathrm{ha}^{-1}\right)$ & 800 & 1000 & 600 \\
\hline Price (US\$ $\mathrm{kg}^{-1}$ ) & 4.00 & 3.00 & 1.50 \\
\hline Income (US\$) & 3200.00 & 3000.00 & 900.00 \\
\hline \multicolumn{4}{|l|}{ Costs } \\
\hline Land preparation (US\$) & 40.00 & 40.00 & 40.00 \\
\hline Labour cost (US\$) & 50.00 & 50.00 & 50.00 \\
\hline Seed cost (US\$) & 100.00 & 120.00 & 37.50 \\
\hline Fertiliser cost (US\$) & 150.00 & 150.00 & 150.00 \\
\hline Chemicals (US\$) & 50.00 & 40.00 & 40.00 \\
\hline Total costs (US\$ ha-1) & 390.00 & 400.00 & 317.50 \\
\hline Gross margin (US\$ ha-1) & 2810.00 & 2600.00 & 582.50 \\
\hline Cost per seed (US\$) & 0.49 & 0.40 & 0.53 \\
\hline
\end{tabular}


However, further studies need to be conducted to ascertain forage seed production levels and profits, decision-making within the household, seed distribution pathways and the contribution of forage seed production and marketing to smallholder farmers' livelihoods.

\section{References}

Alemu K. 2015. Seed production and dissemination systems analyses: the case of Ethiopia. Food Science and Quality Management 35: 25-37.

Ambrosano EJ, Cantarella H, Ambrosano GMB, Dias FLF, Rossi F, Trivelin PCO, Muraoka T. 2013. The role of green manure nitrogen use by corn and sugarcane crops in Brazil. Journal of Agricultural Sciences 4(12A): 89-108.

Ayan I, Mut H, Basaran U, Acar Z, Asci OO. 2012. Forage potential of cowpea. Turkish Journal of Field Crops 17: 135-138.

Belewu MA, Olajide JO. 2010. Lesser known seed: a renewable pathway for sustainable animal production in Africa. Journal of Sustainable Development in Africa 12: 179-188.

Beshir H. 2014. Factors affecting the adoption and intensity of use of improved forages in North East Highlands of Ethiopia. American Journal of Experimental Agriculture 4: 12-27.

Beyene F. 2010. The role of NGO in informal seed production and dissemination: the case of eastern Ethiopia. Journal of Agriculture and Rural Development in the Tropics and Subtropics 111: 79-88.

Buwu V. 2014. Intensification of smallholder beef production systems using tropical forage legumes. MSc thesis, University of Zimbabwe, Zimbabwe.

Clark R, Timms J (eds). 1999. Enabling continuous improvement and innovation: focused thinking and action for impact on performance. Gatton: The Rural Extension Centre.

D'Mello JPF, Devendra C.1995. Anti-nutritional substances in legume seeds. In: D'Mello JPF, Devendra C (eds), Tropical legumes in animal nutrition. Wallingford: $\mathrm{CAB}$ International. pp 135-172.

Etwire PM, Atokple IDK, Buah SSJ, Abdulai AL, Karikari AS, Asungre P. 2013. Analysis of the seed system in Ghana. International Journal of Advance Agricultural Research 1: 7-13.

FAO (Food and Agriculture Organization of the United Nations). 2011. World livestock 2011: livestock in food security. Rome: FAO.

Guei RG, Barra A, Silue D. 2011. Promoting smallholder seed enterprises: Quality seed production of rice, maize, sorghum and millet in Northern Cameroon. International Journal of Agricultural Sustainability 9: 91-99.

Hare MD. 2014. Village-based tropical pasture seed production in Thailand and Laos-a success story. Tropical Grasslands Forrajes Tropicales 2: 165-174.

Hare MD, Phengphet S, Songsiri T, Sutin N, Vernon ESF, Stern E. 2013. Impact of tropical forage seed development in villages in Thailand and Laos: research to village farmer production to seed export. Tropical Grasslands - Forrajes Tropicales 1: 207-211.

Mapiye C, Foti R, Chikumba N, Poshiwa X, Mwale M, Chivuraise C, Mupangwa JF. 2006. Constraints to adoption of forage and browse legumes by smallholder dairy farmers in Zimbabwe. Livestock Research for Rural Development 18(12): Art. \#175.

Martey E, Etwire PM, Wiredu AN, Dogbe W. 2014. Factors influencing willingness to participate in multi-stakeholder platform by smallholder farmers in northern Ghana: implication for research and development. Agricultural and Food Economics 2: 11.

Mhlanga B, Cheesman S, Maasdorp B, Mupangwa W, Thiefelder C. 2015. Contribution of cover crops to the productivity of maize-based conservation agriculture systems in Zimbabwe. Crop Science 55: 1791-1805.

Murphy AM, Colucci PE. 1999. A tropical forage solution to poor quality ruminant diets: a review of Lablab purpureus. Livestock Research for Rural Development 11: 2:

Njingulula $P$, Wimba $P$, Musakamba $M$, Masuki KF, Katafiire $M$, Ugen M, Birachi E. 2014. Strengthening local seed systems within the bean value chain: experience of agricultural innovation platforms in the Democratic Republic of Congo. African Crop Science Journal 22: 1003-1012.

Phaikaew C, Guodao L, Abdullah A, Tuhulele M, Magboo E, Bouahom B, Stür W. 1997. Tropical forage seed production in Southeast Asia: current status and prospects. In: Proceedings of the XVIII International Grassland Congress, 8-19 June 1997, Winnipeg and Saskatoon, Canada, vol. 2. [s.I.]: International Grassland Conference. pp 28-7-28-8.

Roothaert RL, Olufajo OO, Bezkorowajnyj PG, Ravinder Reddy Ch, Prasad VL. 2006. A multi-stakeholder approach to seed systems of food-feed crops for smallholder farmers in the tropics. In: Proceedings of the International Conference on Livestock Services, 17-19 April 2006, Beijing, China. pp 212-222.

Shelton HM, Franzel S, Peters M. 2005. Adoption of tropical legume technology around the world: analysis of success. Tropical Grasslands 39: 198-209.

Singh BB, Ajeigbe HA, Tarawali SA, Fernandez-Rivera S, Abubakar M. 2003. Improving the production and utilization of cowpea as food and fodder. Field Crops Research 84: 169-177.

Thornton PK. 2010. Livestock production: recent trends, future prospects. Philosophical Transactions of the Royal Society B: 365: 2853-2867.

Tsado JH, Ojo MA, Ajayi OJ. 2014. Impact of Training the Trainers' programme on rice farmers' income and welfare in North Central, Nigeria. Journal of Advanced Agricultural Technologies 1: 157-160.

Uzonna UR, Qijie G. 2013. Effect of extension programs on adoption of improved farm practices by farmers in Adana, southern Turkey. Journal of Biology, Agriculture and Healthcare 3: 17-23.

Vissoh P, Manyong VM, Carsky JR, Osei-Bonsu P, Galiba M. 1998. Experiences with Mucuna in West Africa. In: Buckles $D$, Etèka A, Osiname O, Galiba M, Galiano G (eds), Cover crops in West Africa: contributing to sustainable agriculture. Ottawa: International Development Research Centre; Ibadan: International Institute of Tropical Agriculture; Cotonou: Sasakawa Global 2000. pp 1-32.

Welu G. 2015. Challenges and opportunities of seed multiplication in eastern Tigray Ethiopia. Journal of Biology, Agriculture and Healthcare 5: 42-53. 